\title{
The anthropogenic pollutants in urban ponds based on the example of Słupsk
}

\author{
Józef Piotr Antonowicz ${ }^{1}$,Damian Panasiuk ${ }^{2, *}$, Sylwia Machula ${ }^{3}$, Jacek Florian Kubiak ${ }^{3}$, \\ Magdalena Opalińska ${ }^{1}$ \\ ${ }^{1}$ Pomeranian Academy in Słupsk, Department of Environmental Chemistry, Arciszewskiego 22b, \\ 76-200 Słupsk, Poland \\ ${ }^{2}$ Cardinal Stefan Wyszyński University, Faculty of Biology and Environmental Sciences, \\ Wóycickiego 1/3, 01-938 Warszawa, Poland \\ ${ }^{3}$ West Pomeranian University of Technology, Department of Fisheries Management and Water \\ Protection, Królewicza 4, 71-550 Szczecin, Poland
}

\begin{abstract}
In areas of urban infrastructure, ponds play an important role. They are places of rest and recreation, and they facilitate contact between city dwellers and the aquatic environment. They are also a place for living waterflow and ichthyofauna. Urban ponds are susceptible to anthropogenic influences, and their self-cleaning capacity is limited due to their small size. The city of Słupsk is located in northern Poland. Coal combustion in domestic boilers and transport cause dust emissions to be released into the atmosphere. The concentration of particulate matter and heavy metals in PM10 in Słupsk is much higher than in neighbouring village Gać. This affects metals deposition from the atmosphere. Two urban ponds in Słupsk were the object of the research. Sampling station No. 1 was located in the southern part of the Raj Pond situated deep into the forest area, a considerable distance from urban buildings. Sampling station No. 2 was located at the Juniorów Pond located near the city centre. Water samples were taken from a depth of $10 \mathrm{~cm}$. To investigate the deposition from the atmosphere, atmospheric precipitation was collected in a collector located in the city of Stupsk. The concentrations of $\mathrm{Li}, \mathrm{Al}, \mathrm{Cr}, \mathrm{Mn}, \mathrm{Fe}, \mathrm{Ni}, \mathrm{Se}, \mathrm{As}$, $\mathrm{V}, \mathrm{Sr}, \mathrm{Cd}$ and $\mathrm{Pb}$ were analyzed in the obtained water samples. Measurements were made using an ICP-MS mass spectrometer. From the obtained results, it was observed that the concentrations of $\mathrm{Li}, \mathrm{Al}, \mathrm{Cr}, \mathrm{Mn}$, $\mathrm{Fe}, \mathrm{Se}, \mathrm{Sr}$ and $\mathrm{Cd}$ were higher at station No. 2 located near the city centre.
\end{abstract}

\section{Introduction}

In cities, ponds are important places for rest and recreation, they diversify the landscape and are a place of existence for flora and fauna. There are numerous ponds in the area of Słupsk [1]. Urban ponds are usually small objects characterized by low depth. In the hydrobiological sense, the pond fully corresponds to the lake littoral, because basin macrofauna can develop in its entire area [2]. Urban ponds are particularly vulnerable to

\footnotetext{
* Corresponding author: d.panasiuk@uksw.edu.pl
} 
anthropogenic impacts due to frequent contact with urban pollution [3]. They are more susceptible than lakes to the influence of land pollution and their self-cleaning ability is limited by their small size [3, 4].

High traffic, housing and industry density are characteristic features of urban agglomerations. Urban consumption and transport cause the production of significant amounts of a gaseous air pollutants and the generation of dust, which then falls onto urban areas $[5,6]$ and subsequently along with surface runoff can be easily transported to city ponds [6]. Water quality in the European Union is affected by group of priority substances, including metals, in result of economy expansion [7].

In urban agglomerations, specific environmental microclimate conditions are created [5]. Contaminants containing trace elements are dangerous to the health of city dwellers as well as to animals and plants [5, 8]. Municipal and industrial wastes, rainfalls and agriculture are the sources of metals [9]. Most of these substances are toxic to organisms living in lakes such as macroinvertebrates or root macrophytes and contribute to further simplification of the urban lake ecosystem biotic structure $[6,10]$.

The aim of the study was to compare the concentrations of metals in two city ponds with varying degrees of exposure to anthropogenic factors, including the division into the heating season and after heating season. An attempt was also made to analyze the effect of concentrations of metals in PM10 dust and wet precipitation on their concentration in the waters of urban ponds.

\section{Materials and methods}

The city of Słupsk lies in the north of Poland in the Pomeranian region, several kilometres from the coast of the Baltic Sea. According to statistical bureau data [11], the city has 91 935 inhabitants and its area is $43.2 \mathrm{~km}^{2}$. In Stupsk, the local climate is of a transitional character between continental and maritime. The marine features of the climate are associated with influences from the Baltic Sea and the Atlantic Ocean. The characteristic features of the Polish coastal climate are: stronger winds than in other parts of the country, overall higher precipitation with even greater values during autumn and winter, and colder springs and summers [12].

There are several ponds in the city of Słupsk, two of which were similar enough in size and mean depth to be chosen for the study: the Raj Pond and the Juniorów Pond. These are ponds located in areas representing the different character of anthropopression in the city. The Juniorów Pond is located in the Park of Culture and Recreation - on the southern edge of the walking route at Aleja Brzozowa. In its close vicinity there is an urban development with a great advantage of old single-family and multi-family housing. The surface of the pond is $7452.9 \mathrm{~m}^{2}$, and the average depth is $0.8 \mathrm{~m}$ (see Table 1). The Raj Pond is a pond located in the Southern Forest. Its area is $9809.9 \mathrm{~m}^{2}$, and the average depth is $0.7 \mathrm{~m}$ [13]. 
Table 1. Morphometric data of the examined ponds in Stupsk (based on data from the Stupsk city office obtained in 2016).

\begin{tabular}{|c|c|c|}
\hline & Juniorów Pond & Raj Pond \\
\hline Location in Stupsk City & $\begin{array}{c}\text { Park of Culture and } \\
\text { Recreation }\end{array}$ & Southern Forest \\
\hline Area $\left[\mathrm{m}^{2}\right]$ & 7452.9 & 9809.9 \\
\hline Capacity $\left[\mathrm{m}^{3}\right]$ & 6391.8 & 16480.9 \\
\hline Length $[\mathrm{m}]$ & 200.0 & 297.0 \\
\hline Width $[\mathrm{m}]$ & 46.6 & 50.5 \\
\hline Maximum depth $[\mathrm{m}]$ & 1.4 & 4.1 \\
\hline Average depth $[\mathrm{m}]$ & 0.8 & 0.7 \\
\hline Origin & $\begin{array}{c}\text { Stupia river's meander } \\
\text { cutoff }\end{array}$ & clay extraction site \\
\hline
\end{tabular}

The ponds in Słupsk play the role of objects for leisure activities and recreation. Both ponds are used for amateur fishing [14]. There are fish in the ponds. The following species can exist there: Rutilus rutilus (Linnaeus, 1758), Carassius carassius (Linnaeus, 1758), Abramis brama (Linnaeus, 1758), Tinca tinca (Linnaeus, 1758), Esox lucius (Linnaeus, 1758) [14]. The ponds are located at a small distance) from the Stupia river, where there are valued fish such as: Salmo trutta m. Trutta (Linnaeus, 1758), Esox lucius (Linnaeus, 1758) [15].

Water samples were taken from a depth of about $30 \mathrm{~cm}$ below the water surface, each quarter in the years 2008-2009 using a bucket placed on a boom, which ensured the taking of the sample at a considerable distance from the shore. Sampling station (No. 2), located at the Juniorów Pond is in close proximity $(50-300 \mathrm{~m})$ to urban buildings and busy streets (from the west, north and east). The Raj Pond is surrounded by dense shelterbelt. Sampling station (No. 1) was chosen in its southern part because: a) the place is surrounded by a forest, which should limit the inflow of atmospheric pollution, b) it is furthest from large housing estates. Only to the west from the sampling station at a distance of about $100 \mathrm{~m}$ is there a low housing development. Large residential multi-family housing units are located approximately $700-1000 \mathrm{~m}$ to the west and to the north.

After collection, water samples were stored in chemically clean PET containers. The samples were then mineralized in $\mathrm{HNO}_{3}$ Tracepure ${ }^{\circledR}$ (Merck, Germany). A Perkin Elmer Elan DRC mass spectrometer was used to determine the concentrations of metals, i.e. Li, $\mathrm{Al}, \mathrm{V}, \mathrm{Cr}, \mathrm{Mn}, \mathrm{Fe}, \mathrm{Ni}, \mathrm{As}, \mathrm{Se}, \mathrm{Sr}, \mathrm{Cd}, \mathrm{Pb}$. The analyses were performed using ELAN Perkin Elmer SCIEX Instrument Control software. A sample obtained from the water deionizer (Hydrolab company, Poland) was used as a blank. TM-24.3 (water from Lake Ontario, Environment Canada), a reference material, was used to verify the accuracy of the method. In addition, an analysis of the recovery of the sample subjected to the same treatment as the test sample was performed, obtaining recoveries in the range of 97 to $104 \%$ for $\mathrm{Li}, \mathrm{Al}, \mathrm{V}$, $\mathrm{Cr}, \mathrm{Mn}, \mathrm{Fe}, \mathrm{Ni}, \mathrm{As}, \mathrm{Se}, \mathrm{Sr}, \mathrm{Cd}, \mathrm{Pb}$. Statistical analysis was performed by calculating median, mean and standard deviation. It was carried out using Past 3.0 statistical software according to Hammer [16]. 


\section{Results and discussion}

\subsection{Metal concentrations in pond water}

Table 2 presents the basic statistical parameters of the investigated metals in the Raj and the Juniorów ponds in Słupsk. The concentration of tested metals in the Juniorów Pond was ranked according to the following consecutive concentration series: $\mathrm{V}<\mathrm{Cd}<\mathrm{As}<\mathrm{Li}<\mathrm{Cr}$ $<\mathrm{Pb}<\mathrm{Ni}<\mathrm{Se}<\mathrm{Mn}<\mathrm{Sr}<\mathrm{Al}<\mathrm{Fe}$. In the Raj Pond, this series looks as follows: $\mathrm{Cd}<\mathrm{V}<\mathrm{Li}$ $<\mathrm{As}<\mathrm{Cr}<\mathrm{Pb}<\mathrm{Se}<\mathrm{Ni}<\mathrm{Mn}<\mathrm{Al}<\mathrm{Sr}<\mathrm{Fe}$. Higher mean concentrations in the Juniorów Pond compared to the Raj Pond were found for: $\mathrm{Li}, \mathrm{Al}, \mathrm{Cr}, \mathrm{Mn}, \mathrm{Fe}, \mathrm{Se}, \mathrm{Sr}$ and $\mathrm{Cd}$. The same values were found for $\mathrm{V}$, and only for $\mathrm{Ni}, \mathrm{As}$ and $\mathrm{Pb}$, higher concentrations occurred in the Raj Pond. Thus, the impact of urban pollution on the Juniorów Pond located closer to the city centre is visible.

Table 2. Chemical characterization of examined ponds in Słupsk with various levels of anthropopression $\left[\mu \mathrm{g} / \mathrm{dm}^{3}\right]$.

\begin{tabular}{|c|c|c|c|c|c|c|}
\hline \multirow{2}{*}{ Element } & \multicolumn{3}{|c|}{ Juniorów Pond } & \multicolumn{3}{c|}{ Raj Pond } \\
\cline { 2 - 7 } & Mean & Median & SD & Mean & Median & SD \\
\hline $\mathrm{Li}$ & 4.0 & 3.2 & 3.5 & 3.2 & 3.0 & 1.8 \\
\hline $\mathrm{Al}$ & 199.5 & 162.8 & 132.0 & 112.7 & 95.1 & 63.6 \\
\hline $\mathrm{V}$ & 0.5 & 0.1 & 0.7 & 0.5 & 0.1 & 0.7 \\
\hline $\mathrm{Cr}$ & 6.8 & 5.1 & 4.4 & 5.4 & 4.8 & 3.2 \\
\hline $\mathrm{Mn}$ & 96.9 & 68.8 & 93.8 & 64.7 & 12.3 & 88.3 \\
\hline $\mathrm{Fe}$ & 538.0 & 393.0 & 438.0 & 409.2 & 350.2 & 233.8 \\
\hline $\mathrm{Ni}$ & 32.3 & 31.9 & 8.5 & 41.7 & 31.7 & 33.6 \\
\hline $\mathrm{As}$ & 3.0 & 0.9 & 5.0 & 3.9 & 1.0 & 6.5 \\
\hline $\mathrm{Se}$ & 39.2 & 20.0 & 37.8 & 25.3 & 21.2 & 16.5 \\
\hline $\mathrm{Sr}$ & 173.3 & 137.6 & 117.4 & 171.1 & 148.8 & 81.4 \\
\hline $\mathrm{Cd}$ & 0.5 & 0.3 & 0.5 & 0.4 & 0.3 & 0.5 \\
\hline $\mathrm{Pb}$ & 7.3 & 5.9 & 5.1 & 8.1 & 5.9 & 5.2 \\
\hline
\end{tabular}

Figure 1 shows differences in the average concentrations in autumn and winter (heating season) and in spring and summer (after heating season). In the case of the Juniorów Pond in the heating season, higher concentrations occurred for $\mathrm{V}, \mathrm{As}, \mathrm{Cr}$ and $\mathrm{Ni}$. In the case of the Raj Pond, it was $\mathrm{V}, \mathrm{Cr}, \mathrm{Pb}$ and $\mathrm{Ni}$. 

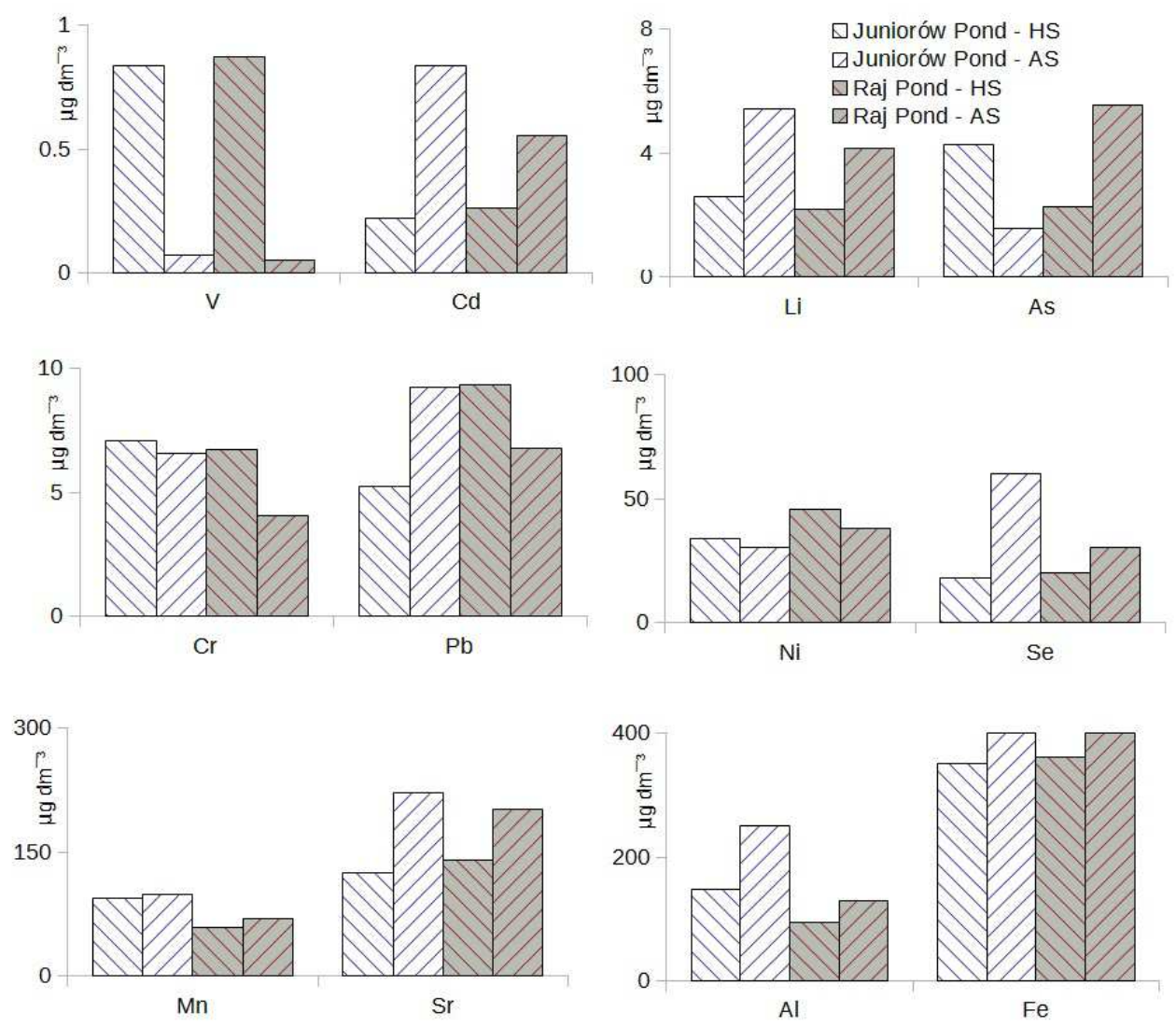

Fig. 1. The average concentrations obtained for $\mathrm{V}, \mathrm{Cd}, \mathrm{Li}, \mathrm{As}, \mathrm{Cr}, \mathrm{Pb}, \mathrm{Ni}, \mathrm{Se}, \mathrm{Mn}, \mathrm{Sr}, \mathrm{Al}$ and $\mathrm{Fe}$ $\left[\mu \mathrm{g} / \mathrm{dm}^{3}\right]$ in the Raj Pond and the Juniorów Pond in heating season (HS) and after heating season (AS).

On the basis of the collected material, the effect of coal combustion in domestic boilers on the level of metal concentrations in pond water was not observed. Only in the case of nickel, chromium and vanadium, higher concentrations in the heating season were observed. Metals could be delivered to the ponds in various ways. Surface waters have three main sources of pollution: wet and dry deposition from the atmosphere, including near and distant sources [17], surface runoff and wastewater discharges [18] and the secondary release of metals accumulated in bottom sediments in earlier periods [19]. Industrial activities and transport in cities are major sources of pollutant emissions into the atmosphere [20]. Since the ponds are located in the city area, and most of the metals tested have achieved higher concentrations in the pond located in a place of higher anthropopression (the Juniorów Pond), it can be assumed that atmospheric pollutants are an important source of metal pollution for the waters of these ponds.

\subsection{Concentration of metals in rain, dust fallout and suspended dust}

Concentrations of metals in surface waters are, among others, the effect of pollution introduced with atmospheric precipitation. The results of historical and contemporary metal concentrations in precipitation in northern and central Poland are presented in Table 3 . The highest concentrations occurred in the 1970s [21]. The results of measurements for the Jeziory station in the Wielkopolski National Park show a small decrease in concentrations 
in the years 1992-2014 [22, 23]. At the Poznań city station, several times higher concentrations of metals in precipitation were observed than at the Jeziory station [23]. Significantly lower concentrations were recorded by the Environmental Protection Inspectorate [24] in the Pomeranian region.

Table 3. Concentration of trace elements in wet precipitation in Poland $\left[\mu \mathrm{g} / \mathrm{dm}^{3}\right]$.

\begin{tabular}{|c|c|c|c|c|c|c|c|}
\hline Element & $\begin{array}{c}\text { Gdynia } \\
\mathbf{1 9 7 6} \\
{[21]}\end{array}$ & $\begin{array}{c}\text { Jeziory, } \\
\mathbf{1 9 9 2 - 9 7} \\
{[22]}\end{array}$ & $\begin{array}{c}\text { Jeziory, } \\
\mathbf{2 0 1 3 - 1 4} \\
{[23]}\end{array}$ & $\begin{array}{c}\text { Poznań, } \\
\mathbf{2 0 1 3 - 1 4} \\
{[23]}\end{array}$ & $\begin{array}{c}\text { Leba, } \\
\mathbf{2 0 1 5} \\
{[24]}\end{array}$ & $\begin{array}{c}\text { Chojnice, } \\
\mathbf{2 0 1 5} \\
{[24]}\end{array}$ & $\begin{array}{c}\text { Gdańsk, } \\
\mathbf{2 0 1 5} \\
{[24]}\end{array}$ \\
\hline $\mathrm{Pb}$ & 64.5 & 6 & $1-13$ & $0-31$ & $0.0-1.3$ & $0.0-1.4$ & $0.1-2.3$ \\
\hline $\mathrm{Ni}$ & 10.8 & 3 & $0-7$ & $0-25$ & $0.0-1.5$ & $0.1-0.5$ & $0.2-0.8$ \\
\hline $\mathrm{Cd}$ & 4.1 & 3 & $0.0-0.2$ & $0.0-0.4$ & $0.02-0.07$ & $0.00-0.08$ & $0.01-0.12$ \\
\hline $\mathrm{Fe}$ & - & 21 & - & - & - & - & - \\
\hline $\mathrm{Mn}$ & 76.0 & 16 & - & - & - & - & - \\
\hline $\mathrm{As}$ & - & - & $0-3$ & $0-8$ & - & - & - \\
\hline $\mathrm{Cr}$ & - & 1 & - & - & - & - & - \\
\hline $\mathrm{Al}$ & - & 0 & - & - & - & - & - \\
\hline
\end{tabular}

In the centre of Poznan the highest median accumulation of metals in rain was detected in the heating season - for $\mathrm{Pb}$ in the winter of 2013/14, for $\mathrm{Ni}$ in the autumn of 2013 and 2014 as well as for $\mathrm{Cd}$ and As in autumn of 2013. The contribution of heavy metals concentration in rainwater from local coal-combustion processes (fuel-based domestic heating) was higher during the winter and lower during the summer [23].

The second source of contamination of surface water is dry dust fallout. The concentration of metals in dust fallout in Szczecin in the north of Poland in 1998 was 272 $\mathrm{mg} \mathrm{Pb} / \mathrm{kg}$ dry matter, $30 \mathrm{mg} \mathrm{Ni} / \mathrm{kg} \mathrm{d.m}$. and $4 \mathrm{mg} \mathrm{Cd} / \mathrm{kg} \mathrm{d.m}$. [5]. Both wet and dry deposition of metals are a result of the concentration of these pollutants in the ambient air. Table 4 shows the concentration of particulate matter and heavy metals in PM10 in the Pomeranian region. In two stations in Słupsk this concentration is much higher (2-3 times) than in neighbouring village Gać. Even higher concentrations were recorded in the largest city in the region - Gdańsk.

Table 4. Average annual concentrations of particulate matter in air and metals in PM10 in the Pomeranian region in 2015 [25].

\begin{tabular}{|c|c|c|c|c|c|}
\hline Pollution & Unit & $\begin{array}{c}\text { Gdańsk, } \\
\text { Glęboka Str., } \\
\mathbf{2 0 1 5}\end{array}$ & $\begin{array}{c}\text { Slupsk, } \\
\text { Orzeszkowej } \\
\text { Str., 2015 }\end{array}$ & $\begin{array}{c}\text { Slupsk, } \\
\text { Kniaziewicza } \\
\text { Str., 2015 }\end{array}$ & $\begin{array}{c}\text { Gać village, } \\
\mathbf{2 0 1 5}\end{array}$ \\
\hline $\mathrm{PM} 10$ & $\mu \mathrm{g} / \mathrm{m}^{3}$ & 27 & 22 & 24 & 15 \\
\hline $\mathrm{PM} 2.5$ & $\mu \mathrm{g} / \mathrm{m}^{3}$ & & - & 14 & - \\
\hline $\mathrm{Pb}$ & $\mathrm{ng} / \mathrm{m}^{3}$ & 15.30 & 10.90 & 7.80 & 3.40 \\
\hline $\mathrm{Cd}$ & $\mathrm{ng} / \mathrm{m}^{3}$ & 0.33 & 0.32 & 0.24 & 0.13 \\
\hline $\mathrm{Ni}$ & $\mathrm{ng} / \mathrm{m}^{3}$ & 1.62 & 1.43 & 1.25 & 1.15 \\
\hline $\mathrm{As}$ & $\mathrm{ng} / \mathrm{m}^{3}$ & 1.03 & 0.99 & 0.90 & 0.57 \\
\hline
\end{tabular}


The results from Warsaw for 2006-2008 show that in the city the heavy metal concentration in PM10 dust was usually higher during the cold period with house heating (0.44-2.30 $\left.\mathrm{ng} \mathrm{Cd} / \mathrm{m}^{3}, 0.10-0.24 \mathrm{ng} \mathrm{As} / \mathrm{m}^{3}\right)$ than during the warm period $(0.30-1.88 \mathrm{ng} \mathrm{Cd} /$ $\left.\mathrm{m}^{3}, 0.07-0.16 \mathrm{ng} \mathrm{As} / \mathrm{m}^{3}\right)$. In the case of $\mathrm{Ni}$, the concentration in PM10 was higher in the warm period $\left(2.35-6.78 \mathrm{ng} / \mathrm{m}^{3}\right)$ than in the cold period $\left(0.80-6.12 \mathrm{ng} / \mathrm{m}^{3}\right)$ [26]. The combustion of fuels (coal, lignite and oil) in stationary sources is the main source of As, $\mathrm{Cd}, \mathrm{Cr}$ and $\mathrm{Ni}$ emission to the atmosphere in Europe [20, 27].

\section{Conclusions}

Water studies in Słupsk urban ponds have shown the influence of the reservoir location on the level of metal concentrations. For most of the tested metals, higher concentrations in water were recorded in the Juniorów Pond which is located closer to the city centre. It can be assumed that this is the effect of urban pollution such as coal combustion in domestic boilers and transport. However, the results of the study did not show a significant effect of house heating on the concentration of metals in the ponds in the autumn and winter (heating season). The level of pollution of water reservoirs is the sum of local factors and wet and dry deposition from the atmosphere. However, it should be noted that the concentration of particulate matter and heavy metals in PM10 was several times higher for measuring stations located in Słupsk than for the station in the neighbouring village of Gać.

\section{References}

1. J.P. Antonowicz, M. Wolska, A. Libera, Balt. Coast. Zone 20, 5-23 (2016)

2. L. Żmudziński, Hydrobiologia: Życie wód słodkich i morskich (WSP Słupsk, 1997)

3. M. Kostecki, M. Krodkiewska, Zbiornik Paprocany. Limnologia - Hydrobiologia. (PAN, Zabrze, 2005)

4. J.P. Antonowicz, J. Kubiak, S. Machula, Limnol. Rev. 16 (3), 115-120 (2016)

5. E. Niedźwiecki, M. Protasowicki, T. Wojcieszczuk, A. Ciemniak, D. Niedźwiecka, Proceedings of the Soil Anthropization VI, 119-125 (2001)

6. L. Nasali-Flores, Proceedings of Taal 2007: The 12th World Lake Conference, 13331337 (2008)

7. K. Sundseth, J.M. Pacyna, E. Pacyna, D. Panasiuk, Water Air Soil Pollut. 223, 429-442 (2012)

8. B.G. Wixson, B.E. Davies, Environ. Sci. Technol. 28(1), 26A-31A (1994)

9. J. Kubiak, A. Nędzarek, Ecol. Chem. Eng. 12(10), 1095-1100 (2005)

10. B.J. Mahler, P.C. Van Metre, E. Callender, Environ. Toxicol. Chem. 25(7), 1698-1709 (2006)

11. GUS, http://www.polskawliczbach.pl/Slupsk (2017)

12. D. Baranowski, M. Kirschenstein, Baltic Coastal Zone 14, 99-120 (2010)

13. Urząd Miasta Słupsk, unpublished data (2016)

14. Polski Związek Wędkarski Słupsk, unpublished data (2017)

15. A. Moczulska, J. Antonowicz, K. Krzyk, Słupskie Pr. Biol. 3, 45-56 (2007)

16. Ø. Hammer, PAST. PAleontological STatistics. Reference manual (Natural History Museum, University of Oslo, 2016) 
17. COHIBA, Work Package 4. Summary report Poland (IETU Institute for Ecology of Industrial Areas, Katowice, 2011)

18. J.R. Dojlido, Chemia wód powierzchniowych (Wyd. Ekonomia i Środowisko, Białystok, 1995)

19. J. Trojanowski, Cz. Trojanowska, Cz. Jańczak, Baltic Coastal Zone 11, 83-101 (2007)

20. J. Pacyna et al., Atmos. Environ. 41, 8557-8566 (2007)

21. P. Szefer, K. Szefer, Sci. Total Environ. 57, 79-89 (1986)

22. B. Walna, J. Siepak, Sci. Total Environ. 239, 173-187 (1999)

23. P. Siudek, M. Frankowski, Atmos. Res. 198, 123-131 (2017)

24. IOŚ Gdańsk, Wyniki badań monitoringowych w woj. pomorskim w 2015 r. (2016)

25. IOŚ Gdańsk, Roczna Ocena Jakości Powietrza. Raport za 2015 r. (2016)

26. G. Majewski, M. Kleniewska, A. Brandyk, Pol. J. Environ. Stud. 20(2), 417-427 (2011)

27. D. Panasiuk, A. Głodek, R. Piątek, E. Pacyna, Ecol. Chem. Eng. S 14(S4), 505-514 (2007) 